\title{
Adam Smith, Thomas Chalmers and the formation of a moral economy
}

\author{
Bill Thomas
}

The commercial world pervades all aspects of modern life and provides for our high standard of living, yet we see significant disparity in living standards within our societies. A just economic order can only be attained through the interaction of moral commercial participants utilizing common moral frameworks. Unfortunately, society offers no mechanism to ensure that citizens maintain their focus on honesty, integrity and benevolence throughout their business careers. I believe the church should and can engage society to help develop and maintain character, and to help restore moral business behaviour throughout.

The modern Western world has witnessed the withdrawal of the Christian church from ongoing foundational moral training of secular society. The church engages with high profile issues like abortion and inequality, and increasingly focuses less on the preparation of individual church members for the implementation of their roles as members of our commercial society.

Eighteenth-century Scotland, with its blend of secular and religious preparation in local communities, may be a good model for the presentday church. The Scottish Enlightenment challenged church dogma, but moral discipline was still imparted through regular worship and parish-based teaching. Universities founded by religious orders prepared new generations of academics and lay leaders. The previous two centuries witnessed an unsuccessful attempt by Calvinists to turn Scotland into a 'godly commonwealth', ${ }^{1}$ yet moral reasoning was still thought about and taught. The Scottish philosopher/educators Adam Smith and Thomas Chalmers demonstrate the rationale for church involvement in seemingly unrelated, even conflicting, moral and economic systems. 
Adam Smith's The Wealth of Nations (WN) and Theory of Moral Sentiments (TMS) informed my pharmaceutical licensing career. Intellectual property licenses are long lasting relationships that require participants to have common moral values around which they base the deal.

I was introduced to Chalmers in 2012. Chalmers contemplated writing against Smith's supposed vision of self-interest in the name of economic good, ${ }^{2}$ yet his actions actually complemented Smith's work. Chalmers understood that the world of self-interested commercial activity must be attenuated by church-taught moral character that viewed others as important beings (as, I believe, did Smith).

\section{The importance of commercial systems to modern society}

Each of us exchanges money, goods or services for goods or services provided by someone else. A simple example can help demonstrate the extent to which our lives depend on this commerce.

Consider the purchase of a latte at the local coffee shop. Below are just a few steps required to make a coffee shop latte:

- Coffee - grow coffee bush at suitable location, harvest bean, ship to distributor/roaster

- Coffee roaster - prepare bean for brew, package and ship to coffee shop

- Milk - raise cow, milk cow, bottle and ship milk to coffee shop

- Coffee shop - pay rent, salaries, utilities, maintain hygiene

- Customer - distribute to coffee shop sufficient funds to complete above tasks

The coffee grower, shipper, roaster, dairy farmer, landlord and barista, each perform their duties in exchange for monetary compensation. Each worker is an agent in our commercial system through their own consumption and the produce of their labour, and each worker contributes to the general welfare through their specific effort (whether a labourer, health care worker, salesperson, etc). The sum of our efforts makes up our economy. 
Billions of commercial interactions succeed each day. Each of us represents a small piece of the world economy. The success of our commercial transactions depends on each one of us properly executing our role as worker, lawmaker and consumer.

There are two important ways in which society facilitates successful commercial transactions. First, legal/regulatory boundaries require that commercial participants provide safe products and services and are honest in dealings. Second, society develops and maintains a common moral framework that ensures each participant understands their moral/ethical obligations in a commercial transaction and knows what to expect from any counterparty. Adam Smith taught the moral framework of virtue when professor of moral philosophy, creating a platform for his later work on commercial systems.

\section{Adam Smith and moral formation}

Adam Smith was born in Kirkcaldy, Scotland in 1723. His father, an attorney and Comptroller of Customs, ${ }^{3}$ died around the time of Smith's birth and left Smith's pious mother to raise him with the help of family and friends. Smith grew up and lived during what Fay calls 'Scotland's Augustan Age'4 and what Buchan more conventionally calls the 'Scottish Enlightenment'.

During the 1600 s, Scotland saw substantial religious and political upheaval. The country was split politically, and the Protestant Reformation created a society heavily influenced by the Calvinist church. Reformers demanded strict adherence to rules-based behavioural models. Scotland united with England in 1707 and the eighteenth-century social structure softened when, as Smith himself observed, the church lost some of its societal influence as internal debate led to the creation of numerous sects, each with ever decreasing community influence. ${ }^{6}$ This Enlightenment environment, filled with discovery across many disciplines, was bounded by the remaining rules-based traditions from the Reformation, and, according to Dow, Scottish economic thought required 'the capacity for moral judgment'.?

Smith brought an amazing talent for observation, assimilation and communication to his analysis of virtuous human behaviour and its 
potential to create a better society through commerce. He lived in a time when observation was much simpler than today. The British Empire was at its height, and trade between countries was well documented. Simple manufacturing systems started in Scotland, and Smith was quick to evaluate how these systems led to improvements in the wellbeing of the population. He approached his analysis from the viewpoint of a moral philosopher. However, he essentially became the founder of the discipline then known as Political Economy.

Early in his career Smith taught moral philosophy, including religion, at the University of Glasgow. Smith clearly stated his beliefs on character in $T M S$ :

When we consider the character of any individual, we naturally view it under two different aspects; first, as it may affect his own happiness; and secondly, as it may affect that of other people. ${ }^{8}$

Smith removed most biblical references from TMS shortly before his death and asked that his executors destroy his religion teaching notes, yet his definition of character closely follows biblical teaching. Moses establishes God's wish that we think of others as we go about our daily lives. Commandments 5-10 position the rights of others and quickly establish order for a properly functioning community (Exod 20:12-17; Deut 5:16-21). Deuteronomy and Leviticus further refine and reinforce the concepts that we are to think of others' rights (Lev 18, 19) Old Testament commandments focus on treatment of Israelite neighbours and visitors to the community, while Jesus clearly broadens the scope to all humanity (Mark 12:31) and establishes the importance of teaching the world His commands (Matt 15:21-28, 28:19-20). ${ }^{9}$ Smith went beyond the creation of rules, he initiated thinking that can be developed into action plans.

Smith believed that humans are born with the need to be approved of by others, and that we learn to behave in ways that others view with approval. ${ }^{10}$ We learn to act as they act. Buchan notes that the idea that we are socialized by our community is an innovation by Smith. We are born with sympathy for one another but must learn our moral reasoning. ${ }^{11}$ We observe others and form what Smith calls 'general 
rules' for our own behaviour. ${ }^{12}$ We learn to apply the general rules, and eventually the rules become part of our personality. Throughout our life, even when our heart is not in agreement with a general rule, we can still choose whether to implement that rule.

Foundations for our behaviour are our sympathy for others and the presence of an internal impartial spectator, our ability to observe ourselves as we pursue our personal interaction. Smith's sympathy is similar to what we now call empathy. We are able to see and perhaps feel the experience of other people. We attempt to understand the good and the bad that others encounter. We then learn how to react to the situations we are presented with. Our reactions should be evaluated by an impartial spectator within us. That spectator is not ourselves, rather we remove ourselves from the situation and judge our behaviour by the general rules we have put in place.

In $T M S$, Smith frequently references a Creator above us (even in the biblically-redacted $6^{\text {th }}$ edition). He believes that human behaviour should attempt to please the Creator. TMS's table of contents identifies propriety, merit of actions, justice and beneficence as major concepts/ traits that Smith used to build more complex moral systems. Smith develops a vision of virtue:

The man who acts according to the rules of perfect prudence, of strict justice, and of proper benevolence, may be said to be perfectly virtuous. But the most perfect knowledge of those rules will not alone enable him to act in this manner: his own passions are very apt to mislead him; ${ }^{13}$

In order to become virtuous, Smith taught that we need some specific skills. Those particularly important to commercial society include the application of prudence, benevolence, commitment to justice, ability to form general rules and a sense of duty to follow them. Our social interactions serve to increase the happiness of others when we serve ourselves at the proper time and manner (prudence), act with forbearance and charity when possible (benevolence), apply the same rules to others as ourselves (justice) and make and follow rules that are agreed to by society (obey the law, contract, social norms). 


\section{Virtue in business}

The formation of commercial agents with a common moral foundation (similar general rules), begins with a person's early learning and continues throughout one's life. Modern commercial society does not reinforce moral behaviour, instead it pressures people to pursue more wealth, work less and value others differently than we value ourselves. Smith might say that society pressures us to deceive ourselves into modifying our general rules. In contrast, a successful economy requires that market participants develop and implement common general rules of integrity, respect for the law and for the value (rights) of others.

A real-world example of the need for Smith's virtuous behaviour in business:

Successful commercial transactions and collaborations require a desire to meet one's own needs, but also an understanding that the counterparty has needs, and that these needs are legitimate. When a US company wishes to develop and market a new German prescription drug in the US, that company needs to obtain a license from the German patent holder to use the German company's scientific and manufacturing data and knowhow, and generally requires ongoing technical and medical support throughout the time the US company markets the product.

Where is the value in this commercial system? Both parties bring identifiable assets to the project. If the management of one company trivializes the value brought by the other company, the partnership will collapse when trouble arises (which always happens), possibly resulting in the removal of a useful medication from the US market. The successful collaboration requires both sympathy for the counterparty and ongoing evaluation of one's own response to each interaction with the counterparty.

If parties work together, self-interested but reasonable and empathetic, then business interactions proceed smoothly. If expectations are reasonable, efforts to fulfill obligations are 
genuine, and mistakes are tolerated, then the parties will modify the partnership to fit changing needs.

In order to maintain flexibility, the parties need to adhere to a similar set of general rules. Those rules form an informal framework for decision-making, and decisions are made in the best interest of the partnership.

Smith notes that self-deceit acts against the traits of virtue and leads one to believe they need to be something other than they initially prepared themselves to be. If the US company described above decides that it needs more of the proceeds from the licensed product than agreed, it may refuse to send royalty payments to the German company, risking litigation, supply disruption and jeopardizing its own reputation and ability to develop future licenses. Individuals may deceive themselves to believe that they need to amass a great fortune in order to fulfill a perceived need for security or recognition, and importantly that societal rules can be broken in pursuit of that fortune. Self-interested behaviour in the pursuit of aberrant values acts against a virtuous economy. Virtuous market participants are needed to build a just economy.

Smith's system of virtue is a foundation upon which successful commercial systems are built.

\section{Smith's commercial system}

Smith observed commercial systems and used 'bottom up' analysis to develop models of commercial systems:

The woollen coat, for example, which covers the day-labourer, as coarse and rough as it may appear, is the produce of the joint labor of a great multitude of workmen. The shepherd, the sorter of the wool, the wool-comber or carder, the dyer, the scribbler, the spinner, the weaver, the fuller, the dresser, with many others, must all join their different arts in order to complete even this homely production. How many merchants and carriers, besides, must have been employed in transporting the materials from some of those 
workmen to others who often live in a very distant part of the country ${ }^{14}$

Smith looked at the individual components of a commercial system, then pieced together those components to form a finished commercial entity. The wool coat did not magically appear, it was created through numerous, identifiable tasks performed by humans. The executed tasks make up the final outcome, in this case the manufacture and delivery of a wool coat.

Smith read, travelled, observed and catalogued experiences relevant to eighteenth-century commerce. Then, he developed conclusions which he transferred to his students and readers. I will attempt to explain my view of Smith's intentions in $W N$ :

The true wealth of a country is expressed in its ability to make and distribute goods that improve the quality of life for all its people. Humans learned that we could make more goods by dividing our labour among specially trained experts (which include common labourers). For instance, a tailor can make more and better clothes than a mother who must necessarily carry out many other tasks.

We use money to pay the experts for their effort, and they in turn pay other experts, including perhaps ourselves, for goods and services. We support our families by trading our effort with others using money as a proxy for our work. Some businesses require upfront capital (money) in order to build buildings or buy machinery used in manufacturing. Banks and investors provide this capital in exchange for a portion of the future excess revenue, the profit, generated by the business.

The system provides for an ever-increasing quality of life for all participants as long as the amount of goods and services increases as the population increases and as long as government intervention is minimized so as to allow the free market, driven by the needs of people, to determine the supply of good and services. Virtuous behaviour using a common moral framework by commercial agents is necessary to effectively execute Smith's economic system, although Smith observes that in his economy 
the numerous virtuous transactions generally overpower those who don't use moral behaviour (liars, the greedy, etc) in the final economy (at least in the mid-eighteenth century).

Behaviour is not always virtuous and $W N$ often focuses on flaws in behaviour to demonstrate how one market participant can disadvantage another. The master tailors of London trained new tailors through apprenticeship. Seven-year, low paid training periods were generally accepted in England, even if not needed to develop a tradesman. Smith details a scenario where greed and self-interest overcame virtue, artificially suppressing the apprentices. In this case, the master tailors persuaded the king to set a limit on apprentices' wages when working in and around London, thus preventing these workers from moving to another master tailor for better wages. Master tailors benefitted from their ability to organize and solicit the king - capabilities not available to their workers. Smith notes,

Whenever the legislature attempts to regulate the differences between masters and their workmen, its counsellors are always the masters. When the regulation, therefore, is in favour of the workmen, it is always just and equitable; but it is sometimes otherwise when in favour of the masters. ${ }^{15}$

Smith sees risk in allowing small groups of self-interested individuals to influence lawmakers. The master tailors effectively lobbied the king to suppress the rights of their workers. ${ }^{16}$ The master tailors discarded justice and removed liberty from their employees, not because of need but purely owing to self-interested greed. If Smith's system of virtue was applied, all parties would recognize the rights of the apprentices to seek the highest wage in exchange for their labour. Smith notes in $W N$,

The property which every man has in his own labour, as it is the original foundation of all other property, so it is the most sacred and inviolable. The patrimony of a poor man lies in the strength and dexterity of his hands; and to hinder him from employing this 
strength and dexterity in what manner he thinks proper without injury to his neighbour, is a plain violation of this most sacred property. ${ }^{17}$

The example of the master tailors helps us see how moral frameworks or general rules play a significant role in commercial society. The virtuous person Smith describes in TMS is the ideal businessperson. The businessperson using a virtuous moral framework would recognize the value of his workers' efforts rather than suppressing their ability to earn. Virtuous businesspeople facilitate fair trade between individuals and between cultures. When implemented, Smith's system facilitates just transfer of wealth from one party to the next and ensures that all parties to the transactions benefit from their input to the transaction.

Smith believed that people formed their moral positions by observing others and he understood that economies were built from the bottom up by real, sometimes virtuous, people. In today's business world, how can we create and maintain virtuous business people? One example lies in the work of Thomas Chalmers.

\section{Thomas Chalmers and training for a virtuous economy}

Thomas Chalmers was born in Anstruther, Scotland in 1780 . He became a minister, prolific author, church reformer and an advocate for a just, Christian society. His methods complement Smith's. Chalmers emphasized biblical teaching, and his life, teaching and actions unintentionally reduced Smith's theories to practice. He effectively advocated for parish-based general education and advocated for the development of a moral commercial society. ${ }^{18}$

Chalmers' seven essays on Christianity's responsibility to and influence on commercial society begin with a biblical quote that shows similar characteristics to Smith's development of the virtuous person: 


\section{DISCOURSE I.}

\section{On the Mercantile Virtues Which May Exist Without the Influence of Christianity}

"Finally, brethren, whatsoever things are true, whatsoever things are honest, whatsoever things are just, whatsoever things are pure, whatsoever things are lovely, whatsoever things are of good report; if there be any virtue and if there be any praise, think on these things." - P HIL iv $8 .{ }^{19}$

In Discourse I, Chalmers addresses the traits of virtue, and recognizes that although the traits existed before the New Testament, we can still use the Bible to focus our view, and to guide and judge our actions. Chalmers' sermons encourage the reader to use their faith to implement God's will. He sees God's frustration with humanity:

God's controversy with our species is not, that the glow of honour or of humanity is never between them. It is, that none of them understandeth, and none of them seeketh after God. It is, that $\mathrm{He}$ is deposed from his rightful ascendancy. It is, that He who in fact inserted in the human bosom every one that principle that can embellish the individual possessor, or maintain the order of society, is banished altogether from the circle of his habitual contemplations. ${ }^{20}$

Chalmers develops the Christian conscience in a manner similar to Smith's impartial spectator. Our conscience is informed by biblical teaching, pleasing both man and God. Our actions, when informed by Christian teaching and guided by our conscience, are virtuous.

Chalmers' remaining commercial discourses discuss themes including honesty, the need for understanding of what it means to have sufficient earthly goods, the risks of selfishness, the importance of those in power setting a good example for others, the importance of communities obeying biblical teaching, and a discussion of the love of money. Order and justice will be maintained when we use God's word to reinforce our virtuous behaviour in the face of temptation. 
Chalmers committed his life to developing church communities throughout much of Scotland. He was a parish minister as well as an academic, writer and church revolutionary. Chalmers believed that it was his duty to prepare his parishes to create communities operating by God's will. Unlike the stern days of post-Reformation Scotland, nineteenth-century Scotland could not be told what to do: instead Chalmers appealed to the positive impacts of a virtuous society.

Chalmers clearly establishes his position on the need for a Christianized citizenry in his work On Political Economy. $\mathrm{He}$ emphasizes that character, not just secular knowledge, is key to the well-being of an economy, and Christian education is the key to development of character. Chalmers notes that the Christian family maintains a certain amount of prudence and 'respectable sufficiency' that those 'with a reckless and precipitate commencement, could never have attained'. ${ }^{21}$ Importantly, Chalmers observes that it is not just the Christian that benefits from demonstrations of Christian morality, but the entire population of the community served by each church. Chalmers claims are not just hypothetical, he developed and implemented Christian education systems throughout his time as a parish minister.

Chalmers' ministries in Kilmaney and Glasgow clearly demonstrate his commitment to developing an informed citizenry. He established the Kilmaney Bible Society in 1812, one of many organizations he founded that were committed to Christian education. ${ }^{22}$ While in Glasgow (1815-19), he structured his church administration in order to provide maximum contact with the 11,000-person parish $(1,100$ attended church) ${ }^{23} \mathrm{He}$ also established a Sunday School system in Kilmaney that grew from 4 to 40 teachers in the final three years of his tenure. ${ }^{24}$ (Unfortunately, his work quickly unravelled after his departure.)

A practising Christian might be expected to have a virtuous moral character, but would this impact his unchurched neighbour? Chalmers firmly believed that the entire community benefitted from the presence of the church, and importantly, from the actions of an active pastor and congregation: 
[...] the secondary influence of Christianity goes a great way farther than its primary or direct influence. For every individual whom it converts, it may, by its reflex operation, civilize a hundred. We have the palpable exemplification of this in Sabbath-schools, where, in a few weeks from their commencement, we may perceive a decency, and a docility, and an improved habit of cleanliness and order, long before there is ground for the assurance, that even so much as one of the pupils has yet been Christianized. ${ }^{25}$

Chalmers concluded that character, formed by exposure to the church, improved the condition of civil society and the economy. He carried a clear message to the political elite of his day - a Christianized society was necessary to achieve a civil society, regardless of whether the members of society were confirmed in their belief in Christ.

\section{Virtuous character and the invisible hand}

Adam Smith may be best known for his suggestion that economies are the sum of individual actions, each guided by an invisible hand and that individual, self-interested transactions produce an economy that may have no resemblance to the intended actions of the individual market participants. ${ }^{26}$ Economists recently developed the concept of game theory, the modern study of the behavioural components of the invisible hand. These complex models demonstrate that economic results are directly related to the sum of individual actions.

Smith recognized the importance of each person's contribution to the final economic outcome. Chalmers recognized that the development of moral character starts with the church, leads to virtuous choices, and promotes a just society. Smith, Chalmers and the church prepared individuals in society to implement virtuous business transactions, a virtuous invisible hand that guides the practising Christian (in theory).

Said another way, in a perfect world, it is the Holy Spirit within each of us, reinforced by ongoing relationships with Christ through continuing engagement with the church, that guides our individual actions as we conduct not only our commercial lives, but all of our daily activities. The Holy Spirit acts through each of us individually 
and will provide a fair and just economy in which to live - the invisible hand of the Holy Spirit at work in and through each of us.

\section{Regulation complements virtuous behaviour}

Society consists of numerous individual economic components, many under the direct control of human beings. If all human decisionmaking were virtuous, there would be no need for regulation because each interaction would be not only self-interested, but in the interest of the counterparty and society in general.

We develop regulations in an attempt to legally bound our human interaction, limiting the effects of extreme self-interest on counterparties to our transactions. Regulation limits the negative effect of extreme self-interest on the invisible hand by limiting the adverse effects of any given transaction. For instance, regulations that limit one's monthly mortgage repayment to a maximum percentage of income are intended to minimize the number of homeowners in foreclosure, and hence reduce stress on the financial system and society as a whole.

Society uses government to develop regulation. Elected officials and professional government employees evaluate and establish rules that regulate much of our commercial interaction with one another. We are led to believe that these rules are always in the best interest of society, yet as we saw with the tailors of London, it is quite easy for a self-interested party to persuade lawmakers to twist regulations such that they no longer benefit the public, but rather artificially benefit the smaller group. How can the church make a difference with the establishment of fair regulation?

Smith and Chalmers understood that a person's heart and head control their actions. This applies to lawmakers as much as it applies to an individual market participant. Ongoing training and encouragement by and from the church might serve to help limit the effect of selfinterested groups on the decisions of lawmakers.

Hopefully the economic examples above are obvious parallels to the systems established in the Old and New Testaments. Moses utilized a system of divine regulation to develop and maintain a moral, just Israelite society, establishing over 600 laws designed to worship 
God and maintain civil order. His law came from God, not influenced by human self-interest groups.

Christ provided grace for those of us unable to live by God's laws, and it is in Him that we find our true ability to flourish. When we are fully engaged with the Holy Spirit, we operate within the moral, if not physical, regulation as delivered by Moses.

The apostle Paul describes the interaction between rules and our behaviour:

What then? Shall we sin because we are not under the law but under grace? By no means! Don't you know that when you offer yourselves to someone as obedient slaves, you are slaves of the one you obey - whether you are slaves to sin, which leads to death, or to obedience, which leads to righteousness? But thanks be to God that, though you used to be slaves to sin, you have come to obey from your heart the pattern of teaching that has now claimed your allegiance. (Rom 6:15-18)

The virtuous citizen supports and complies with regulation designed to benefit all members of society. He/she acts with self-interest informed by regulation and with benevolence for their fellow citizen. Together, a virtuous citizenry maintains a just economy.

\section{Conclusion}

Smith and Chalmers lived during a time when, like ours, formal acceptance of Christ was on the decline, yet they understood that society functions well only when its members interact using a common moral framework. Both believed that virtuous people valued others' needs, not just their own, and that virtue was a teachable skill.

Virtuous common moral frameworks are necessary to engage in even the most basic successful business. Formal secular education in ethical principles prepares one to enter the workforce but lacks ongoing support for the virtuous behaviour required to maintain a just economy. The church can offer continuing support through ministries, like small group study, that encourage personal development. Engagement in the training and support of virtuous community members also provides 
opportunities to demonstrate the value of salvation and redemption while respecting the rights of those who choose not to receive Christ but still see the need to be encouraged in their character.

I once heard Professor N. T. Wright say that our responsibility is to pull forward the kingdom of God into our world, that our job is to make everything 'on earth as it is in heaven'. Every citizen is a part of commercial society, and commerce affects each of us every day. I believe that the church should, and can, impact our economy through the encouragement of moral formation of all society members. We can develop an economy that operates with godly character, but only if we use our collective resources to bring the message of virtue into our entire community.

\section{Notes}

1 Stewart J. Brown, Thomas Chalmers and the Godly Commonwealth in Scotland (Oxford: Oxford University Press, 1982), xvi.

2 Ibid., 40.

3 James Buchan, Adam Smith and the Pursuit of Perfect Liberty (London: Profile Books, 2006), 13.

4 C. R. Fay, Adam Smith and the Scotland of His Day (Cambridge: Cambridge University Press, 1956), 1.

5 Buchan, Adam Smith, 13.

6 Adam Smith, The Wealth of Nations. 1776. Kindle edition, 34850. [Hereafter cited as $W N$ ]

7 Alexander and Sheila Dow, eds., A History of Scottish Economic Thought (Abingdon; New York: Routledge, 2006), 5.

8 Adam Smith, The Theory of Moral Sentiments, 1759. Kindle edition, 183. [Hereafter cited as TMS]

9 For a thorough review of Smith's theology see Paul Oslington, "Theological Readings of Smith", in Adam Smith as Theologian, ed. Paul Oslington (New York: Routledge, 2011), 1-16.

10 Smith, TMS, 94.

11 Buchan, Adam Smith, 55. 
12 Smith, TMS, 10, 11.

13 Ibid., 207.

14 Smith, $W N, 11$.

15 Ibid., 67.

16 Ibid.

17 Ibid., 58.

18 Brown, Thomas Chalmers, 68-70, 74-83, 101-04.

19 Thomas Chalmers, Discourses on the Application of Christianity to the Commercial and Ordinary Affairs of Life (The Works of Thomas Chalmers, D.D. \& LL.D, vol. 6; Glasgow: William Collins, 1836-42), 13.

20 Ibid., 23.

21 Thomas Chalmers, On Political Economy in Connexion with the State and Moral Prospects of Society (Glasgow: William Collins, 1832), 421.

22 Alexander Finlayson, Bitesize Biographies: Thomas Chalmers (Holywell, UK: EP Books, 2015, Kindle Edition), Position 470.

23 Ibid., 520.

24 Ibid., 552.

25 Chalmers, On Political Economy, 426.

26 Smith, $W N, 198$.

\section{Further Bibliography}

Berry, Christopher, Maria Pia Paganelli, and Craig Smith, eds., The Oxford Handbook of Adam Smith. Oxford: Oxford University Press, 2013.

Fulton, Robert Brank, Adam Smith Speaks to Our Times: A Study of His Ethical Ideas. Boston: Christopher Publishing House, 1963.

Göçmen, Doğan, The Adam Smith Problem: Reconciling Human Nature and Society in The Theory of Moral Sentiments and Wealth of Nations. London: Tauris, 2007. 
McLean, Iain, Adam Smith, Radical and Egalitarian: An Interpretation for the Twenty-first Century. Edinburgh: Edinburgh University Press, 2006. 